\title{
Original article (full paper) \\ Physical activity associated with urban environmental characteristics: A correlational study of active women of high socioeconomic status from Brazilian cities of Santa Catarina
}

\author{
Leonessa Boing \\ Adriana Coutinho de Azevedo Guimarães \\ Camila da Cruz Ramos de Araujo \\ Cecilia Bertuol \\ Jorge Fernando Hammes \\ Joris Pazin \\ Mariana Rocha \\ Sara Feltrin \\ Silvia Rosane Parcias \\ Vanessa Terezinha Ferrari Jonck \\ Zenite Machado \\ Adriano Ferreti Borgatto \\ Universidade do Estado de Santa Catarina (UDESC), Florianópolis, SC, Brazil
}

\begin{abstract}
The study aimed to identify urban environmental characteristics, which may be associated with the physical activity (PA) level of women from Brazilian cities of Santa Catarina. The sample was composed of 2047 women aged 20 to 59 from six Santa Catarina cities: Blumenau, Chapecó, Criciúma, Florianópolis, Itajaí, and São José. The PA was evaluated through the IPAQ (short version), and the NEWS to environmental variables. An inferential and descriptive statistic was used: Chi-squared test, ANOVA with post hoc, and raw and adjusted multinomial regression analysis $(p<.05)$. The participants from São José presented greater chances to PA practice when they reside close to appropriated areas, sidewalks, fitness centers, well-lit streets, and when invited by relatives to the practice. The PA Program for the community enables greater chances of practice for women in Florianópolis, São José, Criciúma and Blumenau. As a conclusion, some environmental factors appeared to influence PA practice positively in Catarinense women. Besides that, the fact of belonging to the high economic status could increasingly enable practice, since they seem broader access to gyms and PA private professionals.
\end{abstract}

Keywords: motor activity, health, environment

Resumo - "Atividade física associada com caracteristicas do ambiente urbano: Estudo correlacional com mulheres ativas e nível econômico alto de cidades brasileiras de Santa Catarina." O estudo buscou identificar características do ambiente urbano que podem estar associadas ao nível de atividade física (AF) de mulheres de cidades catarinenses. A amostra foi composta por 2047 mulheres de 20 a 59 anos de seis cidades catarinenses: Blumenau, Chapecó, Criciúma, Florianópolis, Itajaí e São José. A AF foi avaliada por meio do International Physical Activity Questionnaire (versão curta) e o Neighborhood Environmental Walkability Scale para variáveis ambientais. Utilizou-se estatística descritiva e inferencial: Teste do Qui quadrado, ANOVA acompanhada de post hoc e análise de regressão multinomial bruta e ajustada $(p<0,05)$. As mulheres da cidade de São José apresentaram maiores chances para prática de AF quando residem próximas a locais apropriados, calçadas, academias, ruas iluminadas e quando recebem convites de parentes para prática. A existência de Programa de AF para comunidade possibilitou maiores chances de prática para mulheres de Florianópolis, São José, Criciúma e Blumenau. Nas cidades de Florianópolis e Chapecó, os fatores influenciáveis foram respectivamente, beira mar/orla marítima e o convite de parentes para a caminhada. Alguns fatores do ambiente pareceram influenciar positivamente a prática de AF das mulheres catarinenses. Além disso, o fato de pertencerem ao estrato econômico alto pode aumentar a prática, uma vez que as mesmas parecem ter maior acesso as academias e profissionais particulares.

Palavras-chave: atividade motora, saúde, ambiente

Resumen - "Actividad física asociada con medio urbano características: Estudio correlaciónale vivir con mujeres y nivel económico de alta de ciudades brasileñas de Santa Catarina." El estudio trató de identificar las características del 
entorno urbano que puede estar asociado con el nivel de actividad física (AF) de las mujeres catarinenses. Muestra de 2.047 mujeres de 20-59 años de seis ciudades Catarinenses: Blumenau, Chapecó, Criciúma, Florianópolis, Itajaí y São José. AF se evaluó con IPAQ (versión corta) y NEWS a las variables ambientales. Se utilizó estadística descriptiva e inferencial: pruebas Chi cuadrado, ANOVA y análisis post hoc de crudo y ajustado $(p<0,05)$ de regresión multinomial. Las mujeres de São José eran más propensos a practicar cuando AF residen cerca de los lugares, aceras, gimnasios, calles iluminadas apropiadas y por recibir invitaciones de los familiares. La existencia del programa de AF de la comunidad condujo a mayores posibilidades de práctica para las mujeres de Florianópolis, São José, Criciúma y Blumenau. Algunos factores ambientales parecen influir positivamente en la práctica de las mujeres de la AF de Santa Catarina. Además, el facto de pertenecer a los estratos económicos altos puede aumentar la práctica, ya que las mismas parecen tener un mayor acceso a los gimnasios y los profesionales privados de AF.

Palabras claves: actividad motora, salud, medio ambiente

\section{Introduction}

The physical activity (PA) promotes different benefits to the population health, as hypertension risk reduction, diabetes and various types of cancer, aid in the control and reduction of corporal adiposity, besides allowing the increment of cardiovascular, metabolic, and musculoskeletal functions (Bolívar, Daponte, Rodríguez, \& Sánchez, 2010; Ceschini, Andrade, Oliveira, Araújo Júnior, \& Matsudo, 2009; Jurj et al., 2007; Rütten et al., 2001; Serrano-Sanchez, Lera-Navarro, Dorado-García, González-Henriquez, \& Sanchis-Moysi, 2012; Sigmundová, Ansari, \& Sigmund, 2010; World Health Organization, 2010). Such benefits may be positively influenced in a favorable urban environment for the PA practice (Adams et al., 2011; Bolívar et al., 2010; Gustat, Rice, Parker, Becker \& Farley, 2012; Humpel, Owen, \& Leslie, 2002; Sallis, Floyd, Rodríguez, \& Saelens, 2012). However, social changes through decades have been drastically cutting back the daily PA practice by means of the building up of social and environmental barriers (Sallis et al., 2012).

Concerning the practice of PA in women, different barriers of the environment can be found in literature, such as family commitments, the household chores (Jesus \& Jesus, 2012), the issue of insecurity, especially associated with the practice of walk in the evening (Bennet et al., 2007), and the relationship with the environment, such as air pollution, and rainfall incidence (Silva, Petroski, \& Reis, 2009). In addition to such barriers to PA practice, mechanization and facilities of the information age have reduced PA at work and on household chores, as well as government investment in the means of transport technology has reduced the walking time and use of bicycle as a form of moving (Sallis et al., 2012). Understanding the association between the PA and the urban environment, and develop places directed to increase the practice of PA has become an international issue of public health (Humpel et al., 2012; Sallis et al., 2009).

Built urban environments concerning the promotion of PA present strong contribution to the growth of the practice (Sigmundová et al., 2010; Sallis et al., 2009). Some studies, bringing such positive association, were carried out in the United States (Gustat et al., 2012), Australia (Cleland, Ball, \& Crawford, 2013), and Spain (Bolívar et al., 2010), along with the comparison of 11 countries: Belgium, Brazil, Canada, Colombia, China (Hong Kong), Japan, Lithuania, New Zealand, Norway, Sweden and the USA (Sallis et al., 2009). A study developed within European nations (Belgium, Finland, German, Holland, Spain, and Switzerland) pointed that individual good health perception is immediately related to the perception of proper urban environment for the practice of PA (Rütten et al., 2001). Still, some studies point at the socioeconomic status possibly having some influence differently in environment barriers for the PA practice (Cerin et al., 2013; Silva, Petroski \& Reis, 2009).

Studies concerning the association between PA and urban environment are still sparse and present limits, such as lack of local specific characteristics towards PA, in order to target the planning of new environments in a more appealing and coherent manner within the reality (Sallis et al., 2009), mainly in Brazil. The present study aimed to identify the characteristics of the urban environment that may be associated with the level of PA of Catarinense women.

\section{Methods}

\section{Population and sample}

The descriptive correlational study obtained a convenient non-probability sample composed of adult females aged 20 to 59 years from the state of Santa Catarina, in the South of Brazil, resident in Florianópolis, São José, Itajaí, Criciúma, Blumenau, and Chapecó. The exclusion criterion for the cities was the population under 150 thousand inhabitants according to the last census by the Brazilian Institute of Geography and Statistics [IBGE] (2010) carried out in 2010. The latter had the approval of the Ethics Committee - Research in Human Beings of the University of the State of Santa Catarina in 02/03/12, protocol N214/2011.

Despite being a non-probability sample, a calculation was carried out on the sample size, according to Barbetta (2008). Then based on the population of 446,648 women aged 20 to 59 years, from the target cities, following the last census from the IBGE (2010), corresponding to 440 women in Florianópolis, 389 
in São José, 338 in Itajaí, 257 in Blumenau, 325 in Criciúma, and 338 in Chapecó, totalizing 2047 women in the study.

\section{Data collection}

The data collection was carried out from August 2012 to March 2013 and the women invited to take part in the study voluntarily. In order to reach a greater number in female population aged 20 to 59 years, the researchers were in touch with the employing institutions or service providers about the educational background, health, justice, religion, and insurance, considering also the housewives, not presenting the distinction between economic stratum and age. The questionnaires were sent to the participants by email, and then, replied in loco within the presence of the researchers.

A total of 3,054 on-site and online questionnaires was handed in, considering that only 2,047 of them were properly fulfilled returned. As for the printed questionnaires, 183 were inaccurately fulfilled, 165 returned as a blank form, and 174 were lost, either by mail or in stores and companies. Furthermore, 52 online questionnaires were incomplete, 96 did not make to the addressee, due to inaccurate email addresses, and 337 did not return.

\section{Researching tools}

For data collection, a self-applied questionnaire was used, composed of validate instruments, split into four sections:

a) Personal characteristics: concerning age, schooling, marital condition, number of children, weight and height (self-referred) to calculate the Body Mass Index - BMI (weight/height ${ }^{2}$ ). The World Health Organization [WHO] (2004) protocols were used for BMI (weight status) establishing the cut point: underweight (BMI<18.5); normal (BMI 18.5-24.9); overweight (BMI 25.0-29.9); overweight and obesity (BMI>30.0). For statistical ends, the categories were reassembled as follows: regular weight: underweight and regular weight, overweight overweight and obesity.

b) Economical strata: entailing the pattern criteria of economic classification Brazil 2010 - Brazilian Association of Researching Companies [ABEP] (2010), considered the main tool of population segmentation concerning the buying power which classifies the population in economic classes as A, B, $\mathrm{C}, \mathrm{D}$, and $\mathrm{E}$, by means of conversion of the total of schooling referred points of female participants and the quantity of consumer goods in their residence (ABEP, 2010).

c) Physical activity level: evaluated through the International Physical Activity Questionnaire (IPAQ - short version). In Brazil, the questionnaire was validated by the Study Center of the Physical Aptitude Laboratory in São Caetano do Sul - CELAFISCS, the coordinating center of $I P A Q$ in Brazil (Pardini et al., 1997). In the regular PA evaluation, through IPAQ, the following activities were analyzed: the frequency of 10-minute individual and continuous walks, last week moderate and vigorous intensity PA, in different associations, named labor, domestic, leisure, recreational and sport related. Considering that the walk generally demands 3.3METs, that is, a level higher that the cut level for moderate PA (3METs), the total PA which results from a combination of walking, moderate activity, and the vigorous activity, corresponding to at least a moderate activity. The PA was classified into walking, moderate PA, moderate + vigorous, vigorous and total in minutes/day.

d) Perceived environment: an adapted version of the Neighborhood Environmental Walkability Scale (NEWS) was used for the evaluation of the perceived environment, considering PA which evaluates the characteristics of the urban environment (the presence of places for the practice of PA, security, characteristics of the perceived environment, opportunities for the practice of PA, and the quality of streets, sidewalks, and social support), adapted by Reis, Reis, and Hallal (2011). Such scale obtained proper results for internal consistency, validity, and reproducibility, and it was already used in epidemiological studies with adults and the elderly from the Eastern area in São Paulo (Florindo, Salvador, Reis, \& Guimarães, 2011; Salvador, Florindo, Reis, \& Costa, 2009). The first part of the questionnaire was structured so that the participants could respond on how long they would take to get from their residences on foot until different areas, such as commercial, service, or leisure, all of which within their residential neighborhood. The second part of the questionnaire was composed of questions related to social and physical environmental structures (sidewalks, neighborhood appearance, neighbors and friends, presence of places for PA practice, security against the crimes and in the traffic, streetlight, sewerage, garbage, green areas, etc.).

\section{Statistical analysis}

The statistical analysis was carried out through the Statistical Package for Social Sciences (SPSS) - version 20.0. The descriptive statistic was used through calculation of mean, percentile standard deviation. For a comparison of PA types/intensity (walking, vigorous and moderate PA) between the cities studied, the ANOVA was used followed by post hoc test of Bonferroni. The prevalence of PA levels (insufficiently active, active, and very active) was expressed in percentage. The comparison of PA levels between the six cities and the personal characteristics was carried out with Chi square test. The multinomial logistic regression analysis was performed to estimate reasons of adjusted and raw odds ratios for the urban environment features and social support (various independent)z associated with levels of regular PA. The associations that presented value $p \leq .20$ in the bivariate analysis were selected for the entrance into the multiple sample (Hosmer \& Lemeshow, 1989). The sampling was carried out through forward selection strategy. The statistical significance level adopted in the analyses of comparison between groups, and associations between reached variables $p<.05$. 


\section{Results}

Table 1. Characteristics of the participants according to the Catarinense cities, Brazil. 2013.

\begin{tabular}{|c|c|c|c|c|c|c|c|c|c|}
\hline & Total (\%) & Florianópolis (\%) & São José (\%) & Itajaí (\%) & Blumenau (\%) & Criciúma (\%) & Chapecó (\%) & $p$ value & Cramer's V \\
\hline Age & & & & & & & & $<.001$ & .238 \\
\hline 20-32 years & 55.3 & 46.2 & 71.7 & 40.6 & 54.4 & 58.3 & 59.5 & & \\
\hline $33-45$ years & 27.3 & 36.8 & 14.9 & 29.9 & 30.2 & 29.2 & 24.3 & & \\
\hline $46-59$ years & 17.4 & 17.0 & 13.4 & 29.6 & 15.5 & 12.5 & 16.3 & & \\
\hline Marital Status & & & & & & & & .019 & .082 \\
\hline Living Together & 56.4 & 58.7 & 48.6 & 58.9 & 56.9 & 56.2 & 59.4 & & \\
\hline Living Separated & 43.6 & 41.3 & 51.4 & 41.1 & 43.1 & 43.8 & 40.6 & & \\
\hline BMI & & & & & & & & $<.001$ & .124 \\
\hline Regular weight & 62.2 & 70.9 & 66.3 & 55.5 & 63.8 & 54.7 & 59.4 & & \\
\hline Overweight & 37,8 & 29.1 & 33.7 & 44.5 & 36.2 & 45.3 & 40.6 & & \\
\hline Economic Status & & & & & & & & $<.001$ & .365 \\
\hline High & 78.2 & 92.5 & 84.6 & 64.5 & 53.7 & 70.2 & 93.8 & & \\
\hline Middle & 21.6 & 7.5 & 15.4 & 35.5 & 46.3 & 29.8 & 5.0 & & \\
\hline Low & 0.2 & - & - & - & - & - & 1.2 & & \\
\hline Health Status & & & & & & & & $<.001$ & .355 \\
\hline Positive & 95.3 & 100 & 100 & 100 & 83.6 & 83.1 & 100 & & \\
\hline Negative & 4.7 & - & - & - & 16.4 & 16.9 & - & & \\
\hline PA Level & & & & & & & & $<.001$ & .264 \\
\hline Insuf. Active & 32.7 & 20.5 & 31.6 & 28.1 & 34.6 & 48.3 & 36.9 & & \\
\hline Active & 25.9 & 20.0 & 24.4 & 27.5 & 33.5 & 32.2 & 21.3 & & \\
\hline Very active & 41.3 & 59.5 & 44.0 & 44.4 & 31.9 & 19.5 & 41.7 & & \\
\hline
\end{tabular}

BMI: Body Mass Index; PA Level: Physical activity level; Insuf. Active: Insufficiently active.

As it is seen in Table 1, most of the participants are between 20-32 years of age, live together with a partner, present regular weight, belong to a high socioeconomic class and have a positive health status. The PA level for most of those women was set as very active, in which the city of Florianópolis stands out.

Table 2. Raw and adjusted multinomial regression in very active women in relation to the insufficiently active in six Catarinense cities, Brazil, 2013.

\begin{tabular}{|c|c|c|c|c|c|}
\hline & $\%$ & PA Level Raw OR (CI 95\%) & $p^{*}$ & PA Level Adjusted OR (CI 95\%) & $p^{\star *}$ \\
\hline São José & 44.0 & & & & \\
\hline PA Area & & & .054 & & .029 \\
\hline Yes & & $1.81(0.99-3.31)$ & & $5.96(1.20-9.50)$ & \\
\hline No & & Reference & & Reference & \\
\hline Sidewalks\# & & & .039 & & .027 \\
\hline Yes & & $1.90(1.03-3.49)$ & & $2.19(1.09-4.40)$ & \\
\hline No & & Reference & & Reference & \\
\hline Relatives for walking & & & .004 & & .033 \\
\hline Yes & & 2.07(1.27-3.39) & & $1.82(1.05-3.16)$ & \\
\hline No & & Reference & & Reference & \\
\hline Florianópolis & 59.5 & & & & \\
\hline PA Program-community\#\# & & & .001 & & .024 \\
\hline Yes & & $3.46(1.64-7.31)$ & & $2.56(1.13-5.79)$ & \\
\hline No & & Reference & & Reference & \\
\hline São José & 44.0 & & & & \\
\hline PA Program-community\#\# & & & .011 & & .006 \\
\hline Yes & & $2.38(1.22-4.65)$ & & $2.04(1.36-5.96)$ & \\
\hline No & & Reference & & Reference & \\
\hline Chapecó & 41.7 & & & & \\
\hline PA Program-community\#\# & & & .001 & & .023 \\
\hline Yes & & $2.75(1.54-4.89)$ & & $2.45(1.13-5.32)$ & \\
\hline No & & Reference & & Reference & \\
\hline
\end{tabular}

*The reference is the insufficiently active; \# up to 10 minutes walking; \#\#There is physical activity program for the community. 
Table 2 presents the characteristics associated with PA practice in women classified as very active. The women from São José presented more chances for practice when they reside next to appropriate areas for PA (OR=5.96; IC95\%:1.20-9.50), availability of sidewalks (OR=2.19; IC95\%:1.09-4.40), as well as when they are invited by relatives to perform $\mathrm{PA}(\mathrm{OR}=1.82$; IC95\%:1.05-3.16). The existence of a PA program for the community made it possible to have greater chances for the PA practices of the women from Florianópolis, São José, and Criciúma, in comparison to the women from Blumenau, Chapecó, and Itajaí.

As it can be seen in Table 3, the women from Criciúma classified as active had greater chances for PA practice when the existence of a proper area for practice $(\mathrm{OR}=3.04$;
IC95\%:1.15-8.02), and sidewalks on the streets around their residences $(\mathrm{OR}=3.10$; IC95\%:1.11-8.71). In Blumenau, the existence of areas for walking (OR=2.18; IC95\%:1.00-479), and PA programs for the community $(\mathrm{OR}=2.47$; IC95\%:1.17$5.23)$ contributed to the realization of PA. In the city of São José, the chances for practice were greater in the presence of fitness centers $(\mathrm{OR}=2.99$; IC95\%: 1.10-8.16), sidewalks $(\mathrm{OR}=2.67$; IC95\%: 1.16-6.14), and lit streets around the residences $(\mathrm{OR}=1.95$; IC95\%: 1.05-3.63). In the cities of Florianópolis, and Chapecó, the influential factors were, respectively, waterfront (avenue on the shoreline) $(\mathrm{OR}=2.34$; IC95\%: 1.00-5.60), and an invitation from relatives $(\mathrm{OR}=2.45$; IC95\%: 1.02-5.93) for walking.

Table 3. Raw and adjusted multinomial regression in active women in relation to the insufficiently active in six Catarinense cities, Brazil, 2013.

\begin{tabular}{|c|c|c|c|c|c|}
\hline & $\%$ & PA Level Raw OR (CI 95\%) & $p^{*}$ & PA Level Adjusted OR (CI 95\%) & $p^{* *}$ \\
\hline Criciúma & 32.2 & & & & \\
\hline PA Area & & & .010 & & .025 \\
\hline Yes & & $2.53(1.25-5.13)$ & & $3.04(1.15-8.02)$ & \\
\hline No & & Reference & & Reference & \\
\hline Blumenau & 33.5 & & & & \\
\hline Walking Area\# & & & .142 & & .050 \\
\hline Yes & & $1.61(0.85-3.03)$ & & $2.18(1.00-4.79)$ & \\
\hline No & & Reference & & Reference & \\
\hline São José & 24.4 & & & & \\
\hline Fitness Center\# & & & .138 & & .032 \\
\hline Yes & & $0.66(0.38-1.14)$ & & $2.99(1.10-8.16)$ & \\
\hline No & & Reference & & Reference & \\
\hline Florianópolis & 20.0 & & & & \\
\hline **Shoreline\# & & & .172 & & .050 \\
\hline Yes & & $1.57(0.82-2.99)$ & & $2.34(1.00-5.60)$ & \\
\hline No & & Reference & & Reference & \\
\hline Criciúma & 32.2 & & & & \\
\hline Sidewalks\# & & & .027 & & .031 \\
\hline Yes & & $1.78(0.99-3.22)$ & & $3.10(1.11-8.71)$ & \\
\hline No & & Reference & & Reference & \\
\hline São José & 24.4 & & & & \\
\hline Sidewalks\# & & & .036 & & .021 \\
\hline Yes & & $2.25(1.05-4.80)$ & & $2.67(1.16-6.14)$ & \\
\hline No & & Reference & & Reference & \\
\hline Lit Streets & & & .085 & & .034 \\
\hline Yes & & $1.67(1.02-2.74)$ & & $1.95(1.05-3.63)$ & \\
\hline No & & Reference & & Reference & \\
\hline Chapecó & 21.3 & & & & \\
\hline Relatives for Walking & & & .034 & & .046 \\
\hline Yes & & $1.93(1.05-3.54)$ & & $2.45(1.02-5.93)$ & \\
\hline No & & Reference & & Reference & \\
\hline Blumenau & 33.5 & & & & \\
\hline PA Program- community\#\# & & & .067 & & .018 \\
\hline Yes & & $1.84(0.96-3.53)$ & & $2.47(1.17-5.23)$ & \\
\hline No & & Reference & & Reference & \\
\hline
\end{tabular}

*The reference is insufficiently active; \# up to 10 minutes walking; \#\#There is a PA program to the community.

**The term shoreline refers to an avenue built on the waterfront. 


\section{Discussion}

The environment has a great influence in peoples' lifestyle and on the choice power for healthy habits (Florindo et al., 2011). Therefore, it is possible to identify in the present study that the characteristics of the urban environment seem to influence PA practice of women residing in six Catarinense cities. Such participants are mostly young, living with a partner, presenting regular weight, satisfactory financial condition, considering their health status as positive, and are sufficiently active (active+very active). The personal characteristics of women, especially in relation to a satisfactory socioeconomic status, and positive health status, all of which possibly related to the fact that they reside in the cities of Santa Catarina.

The referred state presents a high Human Development Index (HDI), which evaluates dimensions such as education, longevity, and income, reaching the value of .774 in 2010, occupying the third rank in the country (Program from the United Nation for the Development, PNUD 2010). Likewise, in the Santa Catarina state, according to the analysis carried out in the National Research for Samples of Domiciles (PNAD, 2008), $76.6 \%$ of the population considered its health status as good or very good, and $67.4 \%$ had a medical appointment in the 12 months prior the interview date (PNAD, 2008). Considering the findings above, it might be understood that the women included in the present study may maintain the aforementioned characteristics in the state of Santa Catarina, and, to a certain extent, may differ in relation to lower income women, in performing PA in public environments, due to the fact of having more access to gyms and private PA professionals.

The presence of an area for PA, defined in the present study, such as clubs, schools, squares, parks surrounding the residential area, presented itself significant for the women seen as very active in São José, and in the active women in Criciúma. The existence of places for PA practice, namely clubs, soccer fields, churches or religious temples were associated with the practice of PA in adults and elderly leisure in the region of Ermelino Matarazzo, in São Paulo (Florindo et al., 2011; Salvador et al., 2009). It seems that regardless of the socioeconomic status, since the region is classified as low income, the existence of places for the PA practice is associated to the increase of PA practice in leisure. Another study, carried out in another country, namely Hong Kong, with 484 elderly, presented the association between walking as the elderly leisure and the existence of public areas with good structure, including parks (Cerin et al., 2013).

Parks are associated with sport practice, social living, relaxing sites, being with children, getting closer to nature (Chiesura, 2004), promoting PA practice, psychological welfare and improvement of general health of users (Wolch, Byrne, \& Newell, 2014). A study carried out in the city of Curitiba, with 220 men and women, belonging to a high socioeconomic status, looked at the relation of parks with the socioeconomic status of users, identifying that, environment barriers, such as air pollution, increase with the reduction of level in socioeconomic status. And the facilitators of the practice, namely, available equipment, emergency services, and traffic rules are perceived by users as the socioeconomic status gets lower (Silva, Petroski, \& Reis,
2009). In the city of São José, specifically, the presence of fitness centers increased the chance of practice for active women, considering that such women find themselves in a high socioeconomic status, therefore, they seem to have access to fitness centers and are able to pay for the offered services. In Curitiba, a random sample of 1,206 people, whose the existence of gyms around the residences was pointed as an important factor in PA practice in adult participants' leisure (Hino, Reis, Sarmiento, Parra, \& Brownson, 2011).

Such features of the urban environment may be related to a positive perception of the health status in $95 \%$ of the participants. Once there are evidences that changes in the physical environment associated with policies concerning PA may result in favorable modifications in peoples' PA, thus facilitate the variety in behavior entailing positive health (Berrigan \& Troiano, 2002; Evenson, Herring, \& Huston, 2005; Ewing, 2005; Handy, Boarnet, Ewing, \& Killingsworth, 2002; Merom, Bauman, Vita, $\&$ Close, 2003).

In the city of Criciúma, the women classified as active had greater chances for PA practice in the close presence of sidewalks, the same for active women, and very active in São José. In Blumenau, a specific place for walking increased the chance of PA practice of active women, according to the City Hall of Blumenau; such area could be the Park Ramiro Ruediger, which is considered the largest area for leisure in the city. A study performed in Sint-Niklaas, Belgium, with 120 participants, compared two locations in the city. One more qualified for walking, using pedometers for a week, it was found that the greater number of steps was presented by the participants who performed it in the areas with a higher possibility of walking, including the presence of sidewalks (Van Dyck, Deforche, Cardon, \& De Bourdeaudhuij, 2009). Within a significant number of participants $(2,046)$, in Brazil, a study carried out in Recife, identified that the lack of sidewalks is associated with low levels of walking in leisure (Hallal et al., 2010).

The existence of sidewalks has been associated to a greater PA practice, independently of socioeconomic level, since walking is one of the most popular physical activities and has been described as accessible and convenient in the promotion of health among typically sedentary groups and low-income individuals (Alaimo et al., 2008). In Belgium, the urban planning for increasing the walkability level of the cities seem to influence the PA practice and the weight of adults (Van Dyck et al., 2010). McCormack, Shiell, Doyle-Baker, Friedenreich, and Sandalack (2014) show that improvement in features for walkability in urban planning of cities is potentially associated with the improvement of the PA practice level in adults from Canada.

In addition to the physical area for the practice of PA, the social support has gained prominence, that is, invitations from relatives seem to increase the chance of practice of women classified as very active São José and the active women from Chapecó. Corroborating with the results of a cross-sectional study of 890 participants carried out in the region's most populous municipality in Sao Paulo, it is shown that people who are invited to practice PA have more chances to be active in their leisure time (Florindo et al., 2011). In the United States, in a cross-sectional study with 2,025 adults, it was found that 
people with a partner to practice had more chances to achieve the recommendations for the practice of $\mathrm{PA}(\mathrm{OR}=1.47$; IC95\%: 1.15;1.89)(Granner, Sharpe, Hutto, Wilcox, \& Addy, 2007). The study of Giles-Corti and Donovan (2002), with 1,803 healthy individuals from Australia, identified that individuals with partners to practice or attend clubs have a greater chance for the practice of recreational PA. Such data reinforce the importance of investing in environments that stimulate the coexistence of people to provide opportunities for the creation of social networks important for the practice of PA (Florindo et al., 2011).

The existence of a PA program for the community seems to increase the chance of PA practice of very active women in the cities of São José, Florianópolis and Chapecó, as well as the active women in the city of Blumenau. In a populational based cross-sectional study carried out with 3,000 adults living in Gran Canaria (Canary Islands, Spain), the presence of an organized PA program seemed to decrease the level of physical inactivity of participants, related to the social context of the practice, since when it is practiced in a collective performance it promotes cognitive benefits for practioners (Serrano-Sanchez et al., 2012). In another study performed with participants in the metropolitan area of Perth, Australia, it is suggested that participants in organized PA programs have a greater chance of increasing the level of recreational PA practice (Giles-Corti \& Donovan, 2002). In Europe, women who receive opportunities for PA in their community are more active, not only in light and moderate, but also the vigorous activities (Rütten et al., 2001).

In the city of Florianopolis, the waterfront (shoreline) was presented as a significant increase in the chance of PA practice of active women. Such data are also described in the study by Giles-Corti and Donovan (2002), in which the public open spaces and beaches are pointed out as some of the most used places for the practice of PA in the metropolitan area of Perth, Australia. For Bolivar et al. (2010), in a study carried out in Andalusia, a coastal town of Spain, with 6,383 men and 6.708 women, the results indicate that living near the green/natural areas promotes an increase in the PA practice. In areas with pleasant temperatures during the year, the presence of sidewalks, parks, waterfront/shoreline, and cycle paths is a factor of encouragement to the PA practice and the reduction of sedentary habits (Von Hippel \& Benson, 2014). The existence of seafront in Florianópolis may be a determining factor for the PA practice since $79.5 \%$ of women living in this city were sufficiently active, reflecting thus on the BMI, because they were the ones that stood out with the highest percentage of regular weight (70.9 $\%$ ). Specifically, in Brazil, a research carried out in all capitals and in the Federal District (Brasília) showed that $44 \%$ of adults in the city of Florianopolis practice the recommended level of PA in the free time (Vigitel Brasil, 2013).

The security at the place of residence is also one of the characteristics of the urban environment that may influence the practice of PA (Rech et al., 2012). The security may be represented by questions related to the perceived safety of residents in their neighborhood during the day and night, and if they have their lit streets, the latter, as a significant variable, was pointed out by the active women of the city of São José. It seems that the communities of high socioeconomic status may have better urban infrastructure, lighting and safety, when compared to low-income communities, which reflects the PA level in women of the present study. Corseuil, Hallal, Xavier, Schneider, and D'Orsi, (2012) in a study carried out with 1,656 elderlies, verified that feeling safe is related to the increase of PA practice in leisure in the elderly in Florianópolis, as well as in the study of Cerin et al., (2013) with elderlies from Hong Kong, who associated safety with the greater use of parks for the PA practice. Van Dyck et al. (2013), in a study carried out with 6,014 adults in urban cities of the USA, Belgium, and Australia, security was associated with the practice of moderate to vigorous PA in leisure time. The studies showed that women who felt unsafe at night walked less than those who identified their neighborhoods as safe (Bennet et al., 2007). The women who reported the presence of lit streets had a greater likelihood of practicing PA in leisure time (Velasquez, Holahan, \& You, 2009). Therefore, it is important to note that improvements in lighting and aesthetics may contribute to the reduction of the lack of security feelings and perceptions of crime in neighborhoods (Painter, 1996).

The association of features of the urban environment with the behavior of individuals in relation to PA is complex, and the associated factors may be changed, depending on the region, country or context in which the study is carried out (Bamana, Tessier, \& Vuillemin 2008; Bourdeaudhuij, Sallis, \& Saelens, 2003; Inoue et al., 2009; Salvador et al., 2009).

The present study was carried out by means of a questionnaire, which may represent a limitation since such evaluation method is associated with an estimate of error rate higher than $35-50 \%$ (Welk, 2002). Nevertheless, the recommendations for the activity of physical health improvement are, mostly, based on epidemiological studies that used the same methodology. The selection of the sample may also represent a limitation, considering it is a non-probabilistic sample of convenience, it presented differences in some aspects, such as economic stratum and, making it possible to compare only women with similar characteristics to the sample investigated.

The classification of the present study as cross-sectional is also characterized as limiting factor, since it does not allow establishing cause and effecting relation between the variables. Concerning the assessment of environmental perception and the relationship with the PA practice, it might have been such problem, since it is not possible to establish if the appropriate environment is, in fact, the cause of the PA practice due to the fact there is no monitoring of temporality. Still, the results found in this study may serve as a subsidy to the elaboration of public policies and programs for orientation to the practice of physical activity in accordance with the public health recommendations. Finally, it is important to emphasize the need for further studies that address the aspects addressed in the present research, extending them to other regions, with less populated cities, in order to check the spread of such data.

Throughout the study, it was observed that some factors of the urban environment seem to influence positively the PA practice in active and very active women from Santa Catarina. In this sense, it is necessary that such factors, in particular, a suitable place for the PA practice, the presence of sidewalks and 
fitness centers, invitation from relatives to the PA practice, PA Programs within the community, and the perception of safety, all of which are considered in public policies for promotion of PA.

\section{References}

Adams, M., Sallis, J., Kerr, J., Conway, T.L., Saelens, B.E., Frank, L.D., ... Cain, K.L. (2011). Neighborhood environment profiles related to physical activity and weight status: a latent profile analysis. Preventive Medicine, 52, 326-331. doi: 10.1016/j. ypmed.2011.02.020.

Alaimo, K., Basset, E.M., Wilkerson, R., Petersmarck, K., Mosack, J., Mendez, D., ... Stegmier, L. (2008). The Promoting ActiveCommunities program: Improvement of Michogan's SelfAssessment Tool. Journal of Physical Activity and Health, 5, 4-18. Associação Brasileira de Empresas de Pesquisa (Brasil) - ABEP. (2010). Critério de Classificação Econômica Brasil. Retrieved from: [http:// www.abep.org/criterio-brasil].

Bamana, A., Tessier, S., \& Vuillemin, A. (2008). Association of perceived environment with meeting public health recommendations for physical activity in seven European countries. Journal of Public Health, 30, 1-8. doi: 10.1093/pubmed/fdn041.

Barbetta, P.A. (2008). Estatística aplicada às ciências sociais (Applied statistics to social sciences) (7 ed. Ver). Florianópolis: Editora da UFSC.

Bauman, A., Bull, F., Chey, T., Craig, C.L., Ainsworth, B.E., Sallis, J.F., ...\& The I.P.S. (2009). The International Prevalence Study on Physical Activity: results from 20 different countries. International Journal of Behavioral Nutrition and Physical Activity, 6(89), 21-32. doi: 10.1186/1479-5868-6-21.

Bennet, G.G., Mcneill, L.H., Wolin, K.Y., Duncan, D.T., Puleo, E., \& Emmons, K.M. (2007). Safe To Walk? Neighborhood safety and physical activity among public housing residents. PLoS Medicine, 4, 1559-1607. doi: 10.1371/journal.pmed.0040306

Bernstein, M.S., Costanza, M.C., \& Morabia, A. (2001). Physical activity of urban adults: a general population survey in Geneva. Soz Praventivmed, 46, 49-59. doi: 10.1007/BF01318798

Berrigan, D., \& Troiano, R.P. (2002). The association between urban form and physical activity in U.S. adults. American Journal of Preventive Medicine, 23(Supp12), 74-79. doi: 10.1016/ S0749-3797(02)00476-2

Bolívar, J., Daponte, A., Rodríguez, M., \& Sánchez, J.J. (2010). The influence of individual, social and physical environment factors on physical activity in the adult population in Andalusia, Spain. International Journal of Environmental Research and Public Health, 7, 60-77. doi: 10.3390/ijerph7010060.

Bourdeaudhuij, I., Sallis, J.F., \& Saelens, B. (2003). Environmental Correlates of Physycal Activity in a Sample of Belgian Adults. American Journal of Health Promotion, 18, 83-92. doi: 10.4278/0890-1171-18.1.83

Cerin, E., Lee, K.Y., Barnett, A., Sit, C.H., Cheung, M.C., \& Chan, W.M. (2013). Objectively-measured neighborhood environments and leisure-time physical activity in Chinese urban elders. Preventive Medicine, 56, 86-89. doi: 10.1016/j. ypmed.2012.10.024.

Ceschini, F.L., Andrade, D.R., Oliveira, L.C., Araújo Júnior, J.F., \& Matsudo, V.K.R. (2009). Prevalence of physical inactivity and associated factors among high school students from state's public schools. Jornal de Pediatria, 85, 301-306. doi:10.2223/JPED.1915.

Chiesura, A. (2004). The role of urban parks for the sustainable city. Landscape and Urban Planning, 68, 129-138. doi:10.1016/j. landurbplan.2003.08.003

Cleland, V., Ball, K., \& Crawford, D. (2013). Is a perceived supportive physical environment important for self-reported leisure time physical activity among socioeconomically disadvantaged women with poor psychosocial characteristics? An observational study. BMC Public Health, 13, 280. doi:10.1186/1471-2458-13-280

Corseuil, M.W., Hallal, P.C., Xavier, C.H., Schneider, I.J.C., \& D'Orsi, E. (2011). Safety from crime and physical activity among older adults: a population-based study in Brazil. Journal of Environmental and Public Health, 2012(641010), 1-7. doi: 10.1155/2012/641010

Evenson, K.R., Herring, A.H., \& Huston, S.L. (2005). Evaluating change in physical activity with the building of a multi-use trail. American Journal of Preventive Medicine, 28(Suppl 2), 177-1785. doi:10.1016/j.amepre.2004.10.020

Ewing, R. (2005). (2005). Can The Physical Environment Determine Physical Activity Levels? Exercise and Sport Sciences Reviews, 33, 69-75.

Florindo, A.A., Salvador, E.P., Reis, R.S., \& Guimarães, V.V. (2011). Percepção do ambiente e prática de atividade física em adultos residentes em região de baixo nível socioeconômico (Environmental perception and practice of physical activity in adults living in low socioeconomic level region). Revista de Saúde Pública, 45, 302-10. http://dx.doi.org/10.1590/S0034-89102011000200009

Giles-Corti, B., \& Donovan, R. (2002). The relative influence of individual, social and physical environment determinants of physical activity. Social Science \& Medicine, 54, 1793-1812. doi: 10.1016/ S0277-9536(01)00150-2

Gomes, V.B., Siqueira, K.S., \& Sichieri, R. (2001). Atividade física em uma amostra probabilística da população do município do Rio de Janeiro (Physical activity in a probabilistic sample of the population of the municipality of Rio de Janeiro). Cadernos de Saúde Pública, 17, 969-976. http://dx.doi.org/10.1590/ S0102-311X2001000400031

Granner, M.L., Sharpe, P.A., Hutto, B., Wilcox, S., \& Addy, C.L. (2007). Perceived individual, social, and environmental factors for physical activity and walking. Journal of Physical Activity and Health, 4, 278-293.

Gustat, J., Rice, J., Parker, K., Becker, A.B., \& Farley, T.A. (2012). Effect of Changes to the Neighborhood Built Environment on Physical Activity in a Low-Income African American Neighborhood. Preventing Chronic Disease, 9, 110-165. http:// dx.doi.org/10.5888/pcd9.110165

Hallal, P.C., Reis, R.S., Parra, D.C., Hoehner, C., Brownson, R.C., \& Simões, E.J. (2010). Association between perceived environmental attributes and physical activity among adults in Recife, Brazil. Journal of Physical Activity and Health, 7(Suppl 2), S213-22.

Handy, S.L., Boarnet, M.G., Ewing, R., \& Killingsworth, R.E. (2002). How the built environment affects physical activity: views from urban planning. American Journal of Preventive Medicine, 23(Suppl2), 64-S73. doi:10.1016/S0749-3797(02)00475-0

Hino, A.A., Reis, R.S., Sarmiento, O.L., Parra, D.C., \& Brownson, R.C. (2011). The built environment and recreational physical activity 
among adults in Curitiba, Brazil. Preventive Medicine, 52, 419-422. doi: 10.1016/j.ypmed.2011.03.019

Hosmer, D.M., \& Lemeshow, S. (1989). Applied logistic regression. New York, John Wiley \& Sons.

Humpel, N., Owen, N., \& Leslie E. (2002). Environmental factors associated with adults' participation in physical activity: a review. American Journal of Preventive Medicine, 22, 188-199. doi:10.1016/S0749-3797(01)00426-3

Inoue, S., Murase, N., Shimomitsu, T., Ohya, Y., Odagiri, Y., Takamiya, T., Ishii, K., Katsumura, T., \& Sallis, J.F. (2009). Association of physical activity and neighborhood environment among Japanese adults. Preventive Medicine, 48, 321-325. doi: 10.1016/j. ypmed.2009.01.014.

Instituto Brasileiro de Geografia e Estatística (The Brazilian Institute of Geography and Statistics) (2010). Projeção da população do Brasil/censo 2010 (Projection of the population of Brasil/census 2010). Retrieved from: [http//www.ibge.gov.br].

Jesus, G.M., \& Jesus, E.F.A. (2012). Nível de atividade física e barreiras percebidas para a prática de atividades físicas entre policiais militares (Physical activity level and perceived barriers to the practice of physical activities among military police). Revista Brasileira de Ciências do Esporte, 34, 433-448. http://dx.doi.org/10.1590/ S0101-32892012000200013

Jurj, A., Wen, W., Gao, Y-T., Matthews, C.E., Yang, G., Li, H.L., ... Shu, X. (2007). Patterns and correlates of physical activity: a cross-sectional study in urban Chinese women. BMC Public Health, 7, 213. doi: 10.1186/1471-2458-7-213

McCormack, G.R., Shiell, A., Doyle-Baker, P.K., Friedenreich, C.M., \& Sandalack, B.A. (2014). Subpopulation differences in the association between neighborhood urban form and neighborhood-based physical activity. Health \& Place, 5(28C), 109-15. doi:10.1016/j. healthplace.2014.04.001

Merom, D., Bauman, A., Vita, P., \& Close, G. (2003). An environmental intervention to promote walking and cycling--the impact of a newly constructed Rail Trail in Western Sydney. Preventive Medicine, 36, 235-242. doi:10.1016/S0091-7435(02)00025-7

Monteiro, C.A., Moura, E.C., Jaime, P.C., Lucca, A., Florindo, A.A., Figueiredo, I.C.R., Bernal, R. \& Silva, N.N. (2005). Monitoramento de fatores de risco para doenças crônicas por entrevistas telefônicas (Monitoring of risk factors for chronic diseases for telephone interviews). Revista de Saúde Pública, 39, 47-57. http://dx.doi.org/10.1590/S0034-89102005000100007

Painter, K. (1996). The influence of street lighting improvements on crime, fear and pedestrian street use, after dark. Landscape and Urban Planning, 35, 193-201. doi:10.1016/0169-2046(96)00311-8

Pardini, R., Matsudo, S., Matsudo, T.A.V., Andrade, E., Braggion, G., Andrade, D., \& Braggion, G. (1997). Validation of the international physical activity questionnaire (IPAQ): pilot study in Brazilian young adults. Medicine \& Science in Sports \& Exercise, 29, S5-S9.

Pesquisa Nacional por Amostra de Domicílios (National research for sample of Domiciles) (2008) Volume 29. Instituto Brasileiro de Geografia e Estatística (The Brazilian Institute of Geography and Statistics). Retrieved from: [http://www.ibge.gov.br/home/estatistica/populacao/trabalhoerendimento/pnad2008/brasilpnad2008.pdf]

Programa das Nações Unidas para o Desenvolvimento (United Nations Development Programme) (2010). Valores e Desenvolvimento
Humano (Values and Human Development), Brasília. Retrieved from: [http://www.pnud.org.br/]

Rech, C.R., Reis, R.S., Hino, A.A., Rodriguez-Añez, C.R., Fermino, R.C., Gonçavels, P.B., Hallal, P.C. (2012). Neighborhood safety and physical inactivity in adults from Curitiba, Brazil. International Journal of Behavioral Nutrition and Physical Activity, 12, 72. doi:10.1186/1479-5868-9-72

Reis, M.S., Reis, R.S., \& Hallal, P.C. (2011). Validade e fidedignidade de uma escala de avaliação do apoio social para a atividade física. Revista de Saúde Pública, 45, 294-301. http://dx.doi.org/10.1590/ S0034-89102011000200008

Rütten, A., Abel, T., Kannas, L., Von Lengerke, T., Lüschen, G., Diaz, J.A., ... Zee, J. (2001). Self reported physical activity, public health, and perceived environment: results from a comparative European study. Journal of Epidemiology and Community Health, 55, 139-146. doi: 10.1136/jech.55.2.139

Sallis, J., Bowles, H., Bauman, A., Ainsworth, B.E., Bull, F.C., Craig, C.L., ... Bergman, P. (2009). Neighborhood environments and physical activity among adults in 11 countries. American Journal of Preventive Medicine, 36, 484 490. doi: 10.1016/j.amepre.2009.01.031.

Sallis, J., Floyd, M., Rodríguez, D., \& Saelens, B.E. (2012). Role of built environments in physical activity, obesity, and cardiovascular disease. Circulation, 125, 729-737. doi: 10.1161/ CIRCULATIONAHA.110.969022.

Salvador, E.P., Florindo, A.A., Reis, R.S., \& Costa, E.F. (2009). Percepção do ambiente e prática de atividade física no lazer entre idosos (Environmental perception and practice of physical activity in leisure among elderly). Revista de Saúde Pública, 43, 972-80. http://dx.doi.org/10.1590/S0034-89102009005000082.

Serrano-Sanchez, J., Lera-Navarro, A., Dorado-García, C., GonzálezHenriquez, J.J., \& Sanchis-Moysi, J. (2012). Contribution of individual and environmental factors to physical activity level among Spanish adults. PloS ONE, 7(6), e38693. doi: 10.1371/ journal.pone.0038693

Sigmundová, D., Ansari, W., \& Sigmund, E. (2011). Neighbourhood environment correlates of physical activity: a study of eight Czech regional towns. International Journal of Environme ntal Research and Public Health, 8, 341-357. doi: 10.3390/ ijerph8020341.

Silva, D.A.S., Petroski, E. L., \& Reis, R. S. (2009). Barreiras e facilitadores de atividades físicas em frequentadores de parques públicos (Barriers and facilitators of physical activities in public of public parks). Motriz, 15, 219-227. doi: 10.5016/2243

Sjostrom, M., Oja, P., Hagströmer, M., Smith, B.J., \& Bauman, A. (2006). Health-enhancing physical activity across European Union countries: the Eurobarometer study. Journal of Public Health, 14, 291-300. doi: 10.1007/s10389-006-0031-y

Van Dyck, D., Cerin, E., Cardon, G., Deforche, B., Sallis, J.F., Owen, N. \& Bourdeaudhuij, I. (2010). Physical activity as a mediator of the associations between neighborhood walkability and adiposity in Belgian adults. Health \& place, 16, 952-960. doi: 10.1016/j. healthplace.2010.05.011.

Van Dyck, D., Cerin, E., Conway, T., De Bourdeaudhuij, I., Owen, N., Kerr, J., ... Sallis, J.F. (2013). Perceived neighborhood environmental attributes associated with adults' leisure-time physical activity: findings from Belgium, Australia and the USA. Health \& place, 19, 59-68. doi: 10.1016/j.healthplace.2012.09.017. 
Van Dyck, D., Deforche, B., Cardon, G., \& De Bourdeaudhuij, I. (2009). Neighbourhood walkability and its particular importance for adults with a preference for passive transport. Health \& place, 15, 496-504. doi: 10.1016/j.healthplace.2008.08.010.

Velasquez, K.S., Holahan, C.K., \& You, K. (2009). Relationship of perceived environmental characteristics to leisure-time physical activity and meeting recommendations for physical activity in Texas. Preventing Chronic Disease, 6, 1-16.

Vigitel Brasil (2013). Vigilância de Fatores Risco e Proteção para Doenças Crônicas por Inquérito Telefônico (Surveillance of Risk Factors and protection for chronic diseases by Telephone Survey). Ministério da Saúde, Secretaria de Vigilância em Saúde - Brasília: Ministério da Saúde. Retrieved from: [http://bvsms.saude.gov.br/ bvs/publicacoes/vigitel_brasil_2014.pdf]

Von Hippel, P., \& Benson, R. (2014). Obesity and the Natural Environment Across US Counties. American Journal of Public Health, 104, 1287-1293. doi: 10.2105/AJPH.2013.301838.

Welk, G. (2002). Physical Activity Assessments for Health-Related Research. Champaign: Human Kinetics.

Wolch, J., Byrne, J., \& Newell, J. (2014). Urban green space, public health, and environmental justice: The challenge of making cities "just green enough." Landscape and Urban Planning, 125, 234244. doi:10.1016/j.landurbplan.2014.01.017

World Health Organization (2004). Global Strategy on Diet, Physical Activity and Health. Available from: [http://www.who.int/ dietphysicalactivity/strategy/eb11344/

strategy_english_web.pdf]

World Health Organization (US). (2010). Global Recommendations on Physical Activity for Health. Available from: [http://apps.who.int/ iris/bitstream/10665/44399/1/9789241599979_eng.pdf]

\section{Authors' note}

Leonessa Boing and Camila da Cruz Ramos de Araujo are master's students in the graduate program in human movement at the Universidade do Estado de Santa Catarina (UDESC). Scholarship from the Coordination for Improvement of Higher Education (CAPES).

Cecilia Bertuol has a master's degree in physical education from the Universidade Federal de Santa Catarina (UFSC). Scholarship from the Coordination for Improvement of Higher Education (CAPES).

Adriano Ferreti Borgatto is a faculty member from the Department of Informatics and Statistics from the Universidade Federal de Santa Catarina (UFSC).

Joris Pazin, Silvia Rosane Parcias, Zenite Machado, and Adriana Coutinho de Azevedo Guimarães are $\mathrm{PhD}$ professors of the Department of Physical Education at the Center for Health Sciences and Sports from the Universidade do Estado de Santa Catarina (UDESC).

\section{Corresponding author}

Leonessa Boing

Laboratório de Pesquisa em Lazer e Atividade Físca (LAPLAF); Centro de Ciências da Saúde e do Esporte (CEFID); Universidade do Estado de Santa Catarina (UDESC). Rua Pascoal Simone, 358, Coqueiros. CEP: 88080-350. Florianópolis, SC.

Telefone: +55 4799156255

E-mail: leonessaboing@gmail.com

Manuscript received on October 9, 2014

Manuscript accepted on August 24, 2015

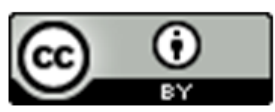

Motriz. The Journal of Physical Education. UNESP. Rio Claro, SP, Brazil - eISSN: 1980-6574 - under a license Creative Commons - Version 3.0 